DOI: 10.34015/2523-4552.2020.4.06

УДК 340.1

\author{
Котюк $\boldsymbol{O}_{\text {, }}$ \\ кандидат юридичних наук, \\ асистент кафедри цивільного процесу \\ Інституту права Київського \\ національного університету \\ імені Тараса Шевченка \\ ORCID: 0000-0002-6464-2315
}

Середа Ю., кандидат юридичних наук, доцент, доцент кафедри конституційного, адміністративного та кримінального права Навчально-наукового інституту «Юридичний інститут Державного вищого навчального закладу «Київський національний економічний університет імені Вадима Гетьмана» ORCID: 0000-0001-5244-3573

\title{
СПІРНІ АСПЕКТИ ТРАДИЦІЙНИХ ПІДХОДІВ ДО ВИЗНАЧЕННЯ ПРЕДМЕТА ПРАВОВОГО РЕГУЛЮВАННЯ
}

У статті на основі положень загальної теорії права уточнюються поняття правового регулювання, його предмета та видів. Обгрунтовується, що предмет правового регулювання $\epsilon$ основною підставою не тільки поділу правових норм на галузі права, а й визначення їхніх назв. Привертається увага до того, що правильний з методологічного погляду поділ правових норм на норми матеріального і норми процесуального права у правовій науці помилково використовується й як критерій поділу галузей права на галузі матеріального та процесуального права, що й зумовило появу таких галузей як цивільнопроцесуальне, кримінально-процесуальне та господарсько-процесуальне право, які супроводжуються відповідними кодексами. Автори доводять, що оскільки змістом предмета правового регулювання вказаних галузей права фактично $є$ правовідносини, які складаються в ході судочинства, що випливає з відповідних матеріально-правових відносин, то саме тому вказані кодекси мали б іменуватися кодексами судочинства, що у повній мірі стосується й цивільного процесуального права та відповідного кодексу.

Ключові слова: правове регулювання; предмет правового регулювання; критерії поділу правових норм на галузі права; засоби правового регулювання; предмет цивільно-процесуального регулювання; джерела права.

В статье с учетом положений общей теории права уточняются понятия правового регулирования, его предмета и видов. Обосновывается, что предмет правового регулирования является главным критерием не только раз- 
граничения правовых норм на отрасли права, а и определения их названий. Обращается внимание на то, что правильное с методологической точки зрения разграничение правовых норм на нормы материального и номы процессуального права в правовой науке ошибочно используется и как критерий разграничения отраслей права на отрасли материального и процессуального права, что обусловило появление таких его отраслей, как гражданскопроцессуальное, уголовно-процессуальное и хозяйственно-процессуальное право, которые сопровождаются и соответствующими кодексами. Доказывается, что содержание предмета правового регулирования указанных отраслей права дает основания для вывода о том, что фактически им являются правоотношения, складывающиеся в ходе судопроизводства, вытекающего с соответствующий материально-правовых правоотношений. Именно поэтому указанные кодексы должны были бы именоваться кодексами судопроизводства, что в полной мере касается также гражданского процессуального права и соответствующего кодекса.

Ключевые слова: правовое регулирование; предмет правового регулирования; критерии разграничения правовых норм; средства правового регулирования; предмет гражданско-процессуального регулирования; источники гражданско-процессуального права.

Постановка проблеми. Аналіз літературних джерел, присвячених цивільно-процесуальному праву, дає підстави для висновку, що методологічні підходи до визначення співвідношення предмета вказаної галузі права з їі назвою потребує уточнень, оскільки назва цієї галузі права і назва відповідного кодексу, який $\epsilon$ їі основним джерелом не відповідають предмету їі правового регулювання.

Якщо ж брати до уваги, що наукові дослідження в даному напрямі останнім часом фактично не проводяться, то це зумовлює актуальність додаткового наукового осмислення вказаних проблем та внесення пропозицій, спрямованих на їх розв'язання. 3 урахуванням цього метою даної статті $\epsilon$ дослідження підходів до розуміння предмета правового регулювання, обгрунтування того, що його значення полягає не лише в тому, що він є основним критерієм поділу правових норм на га- лузі права, а й тією ознакою, яка визначає також їх назви, а 3 урахуванням цього - уточнення змісту предмета і назви цивільнопроцесуального права та відповідного кодексу.

Виклад основного матеріалу. Оскільки у правовій науці загальновизнаною $\epsilon$ доктрина пріоритету предмета правового регулювання перед його методом, то при характеристиці правового регулювання цей підхід зумовлює необхідність аналізу насамперед його предмета, тобто того соціального явища, що об'єктивно вимагає застосування юридичних засобів впливу на процеси його виникнення, зміни та припинення. А оскільки поняття «об'єкт» і «предмет» правового регулювання в дослідженнях часто ототожнюється, то слід звернути увагу на необхідність чіткого їх розмежування. При цьому методологічними орієнтирами тут $є$ загальнонаукові підходи, згідно з якими об'єкт пізнання 
являє собою конкретну матеріальну або ідеальну реальність, на яку спрямований пізнавальний процес, а предмет пізнання - це конкретний аспект цієї реальності (об'єкта). Важливим при цьому $\epsilon$ те, що цей підхід стосується й будь-якого іншого виду діяльності, а виходячи з цього, якщо об'єктом правового регулювання $€$ суспільні відносини в цілому, то його предметом $\epsilon$ окремі їхні аспекти, неоднорідність яких зумовлює необхідність поділяти їх на види, а відповідно розрізняти й окремі предмети галузевого регулювання.

Слід при цьому брати до уваги й те, що і суспільні відносини постійно розвиваються та змінюються, і ті їхні аспекти, що підлягають правовому регулюванню, також можуть змінюватися як у процесі власного розвитку, так і залежно від потреб суспільства та політики держави. Водночас різноманітність та особливості тих відносин, що підлягають правовому регулюванню, вимагають вибору відповідних його засобів.

А оскільки предмети правового регулювання окремих його видів, як правило, не збігаються, то саме предмет правового регулювання $\epsilon$ основним критерієм поділу правового регулювання на окремі його види, а правових норм, якими вони врегульовані - на галузі права. Допоміжними критеріями цього поділу, як правило, називають методи правового регулювання, тобто правові засоби, за допомогою яких здійснюється правовий вплив на відповідне коло суспільних відносин та їхніх учасників, а іноді - й функції конкретної галузі, тобто ті специфічні завдання, які вона виконує.

Розрізняючи предмет і методи правового регулювання, часто ра- дять відповісти на питання, що (тобто який вид відносин) врегульовує конкретна галузь права та як вона це здійснює? Наприклад, О. В. Дзера слушно зазначає: «важливо встановити не лише що регулює цивільне право, а й як це здійснюється, якими засобами воно впливає на ці відносини, тобто який метод впливу закладається в цивільно-правове регулювання. От тому специфіка відносин, що регулюються відповідною галуззю права, водночас обумовлює специфіку методу правового регулювання» $[1,19-23]$.

Не випадково традиційно вважається, що галузі права відрізняються не тільки предметом, а методом правового регулювання, що зумовлює й необхідність визначення галузі права як системи правових норм, які властивими їм методами врегульовують конкретний вид суспільних відносин.

Зрозуміло, що іноді цей підхід ученими уточнюється й іншими ознаками. Наприклад, що галузь права це об'єктивно сформована в структурі єдиної системи права в вигляді їі окремої частини група правових інститутів і норм, що регулює суспільні відносини на основі певних принципів і специфічних методів, в силу чого набуває відносної самостійності, стійкості й автономності функціонування [2, 297].

Слід при цьому брати до уваги й те, що оскільки у кожній зі сфер суспільного життя відносини також неоднорідні, то це є підставою поділу кожного їх виду на вужчі, відносно самостійні групи відносин, які мають свої особливості, а отже, й певну самостійність. Наприклад, у сфері конституційно-правових відносин розрізняють відносини, пов'язані 3 
визначенням засад суспільного i державного ладу, прав і свобод громадян, громадянством, безпосереднім народовладдям, здійсненням місцевого самоврядування тощо, а у сфері цивільних відносин - відносини, пов'язані 3 власністю, зобов'язаннями, авторством, успадкуванням тощо, що у свою чергу, зумовлює необхідність і в межах кожної галузі права розрізняти відносно окремі групи правових норм, які врегульовують ці самостійні групи суспільних відносин. Такі групи норм у межах конкретної галузі права, що врегульовують якісно однорідні групи суспільних відносин у межах певного їх виду, називають правовими інститутами. Зокрема, у межах конституційного права - інститути виборчого права, прав людини, громадянства, місцевого самоврядування тощо, а у межах цивільного права - інститути права власності, зобов'язального, авторського, спадкового права, у межах трудового права - трудовий договір, робочий час, час відпочинку, заробітна плата, нормування праці, дисципліна праці та ін.

Отже, правовий інститут - це група правових норм у межах конкретної галузі права, що врегульовує певну групу якісно однорідних суспільних відносин у межах певного їх виду. У свою чергу, кожен правовий інститут складається з певної кількості конкретних правових норм, які $€$ первинним і неподільним елементом правової системи.

Часто при характеристиці та й при систематизації норм окремих галузей права їх поділяють на норми загальної та норми особливої частин, підкреслюючи при цьому, що норми загальної частини визначають джерела цієї галузі права, їх чинність у просторі й часі, дають загальну характеристику цього виду правовідносин - їх поняття, зміст, суб'єктів та об'єктів, визначають загальні принципи відповідальності за порушення норм цієї галузі права тощо. А особлива частина являє собою ті правові інститути, які $€$ їі складовими.

Таким чином, системність права зумовлена системністю суспільних відносин і полягає у тому, що кожна правова норма належить до певного правового інституту, конкретні правові інститути утворюють конкретну галузь права (кожна галузь права, як правило, складається із низки правових інститутів), а всі разом галузі права, які діють у конкретній державі, утворюють систему її права.

При розгляді означених проблем потрібно пам'ятати, що правові норми кожної 3 галузей права закріплені у відповідних правових актах, що зумовлює необхідність розмежовувати й поняття «система права» та «система законодавства». Тобто, система права - це система правил, якими врегульовані суспільні відносини, а система законодавства це ті правові акти, у яких ці правила офіційно викладені і які визнаються джерелами права. 3 урахуванням цього, слід розрізняти, наприклад, «система права України» та «система законодавства України», «система цивільного права» та «система цивільного законодавства», «система цивільно-процесуального права» та «система цивільно-процесуального законодавства» тощо.

Що ж стосується функцій галузей права, тобто основних напрямів його впливу на суспільні відносини та їх учасників, то, наприклад, для 
приватного права ними насамперед є: регулятивна, запобіжна та ін., а для публічного - охоронна, запобіжна, виховна. Хоча кожна галузь права більшою чи меншою мірою виконує й інші функції, а тому при характеристиці конкретної галузі права йдеться лише про те, які з них є домінуючими саме для неї.

Отже, якщо об'єктом правового регулювання є суспільні відносини, то його предметом - правовідносини, тобто ті аспекти суспільних відносин, що врегульовані правовими нормами і які, як наслідок, повинні виникати, змінюватися й припинятися лише у визначений цими нормами спосіб.

А оскільки суспільні відносини неоднорідні, то це дає підстави розрізняти їх види, які врегульовані окремими групами правових норм, що визнані галузями права, кожна 3 яких спрямована на врегулювання окремого виду суспільних відносин, який і $є$ її предметом і який визначає i ïi назву - конституційне, адміністративне, цивільне, сімейне право тощо.

Але у даному контексті важливо звернути увагу й на те, що традиційно в теорії права правові норми згідно зі змістом їхніх приписів поділяють на норми матеріального права, що визначають права та обов'язки учасників правовідносин, які ними врегульовані, та норми процесуального права, які визначають процедуру реалізації цих прав і обов'язків. I по суті - це так. Але оскільки саме цей підхід було використано й у назвах окремих галузей процесуального права, то це зумовило й назви «цивільно-процесуальне», «кримінально-процесуальне», «господарсько-процесуальне» право то- що. Водночас, попри традиційність цього підходу, слід визнати, що він хибний. Адже за такого підходу складається враження, що якщо нормами цивільного права визначені права й обов'язки учасників зобов'язальних правовідносин, то процедура виконання цих зобов'язань мала б визначатися нормами цивільнопроцесуального права, що далеко не так. Водночас фактично якщо нормами цивільного права визначені права та обов'язки учасників відповідних правовідносин, то ними ж визначена й процедура реалізації цих прав і обов'язків. А якщо нормами цивільно-процесуального права визначені права та обов'язки учасників цивільного судочинства, то ними ж визначена й процедура реалізації цих прав і обов'язків.

От тому й слушним є питання, а чи є процесуальні кодекси - Цивільно-процесуальний, Господарськопроцесуальний, Кримінальний процесуальний насправді процесуальними? [3, 22]. Адже якщо виходити 3 визначення матеріального права як системи норм, що визначають права й обов'язки суб'єктів відповідних правовідносин, а процесуального як системи норм, що визначають процедуру реалізації цих прав i обов'язків, то виявляється, що названі кодекси у власному розумінні цього поняття процесуальними кодексами не $\epsilon$. I не випадково, наприклад, Кодекс адміністративного судочинства України адміністративно-процесуальним кодексом у власному розумінні цього поняття яким мали б бути врегульовані окремі види адміністративного провадження, наприклад, по розгляду заяв, скарг і пропозицій, по застосуванню дисциплінарних стягнень 
тощо, не став. Та й провадження у справах про адміністративні правопорушення продовжує здійснюватися загальними судами за процедурою, визначеною Кодексом про адміністративні правопорушення. А оскільки чинні процесуальні кодекси України фактично визначають лише процедуру здійснення відповідних видів судочинства, то логічнішим було б їх і називати кодексами судочинства.

Таким чином, якщо при характеристиці правових норм серед них за змістом потрібно розрізняти норми, які визначають права та обов'язки учасників правовідносин, та норми, які регламентують процедуру реалізації цих прав і обов'язків, тобто - матеріально-правові й процесуальні норми, то на галузевому рівні ця аналогія є хибною, оскільки кожна галузь права визначає не лише права й обов'язки учасників відповідних правовідносин, а й процедуру реалізації ними їхніх прав та обов'язків.

Ігнорування ж цього висновку зумовлює і теоретико-правові, й організаційно-практичні проблеми. Адже за сучасної теоретико-правової доктрини кожна зі сфер матеріальних правовідносин нібито зумовлює потребу й процесуальної регламентації, що i проявляється в наявності відповідних галузей процесуального права - кримінально-процесуального, цивільно-процесуального та господарсько-процесуального. Однак логіка вказаного підходу за аналогією зумовлює необхідність у відповідних галузях процесуального права, які б супроводжували й кожну іншу галузь матеріального права - конституційного, адміністративного, сімейного, тощо. Однак такі галузі проце- суального права відсутні. I не випадково.

Адже, наприклад, об'єктивна необхідність врегулювання суперечностей, що випливають з адміністративних правовідносин, все ж появу адміністративно-процесуального кодексу не зумовила, підтвердженням чого й стала поява Кодексу адміністративного судочинства України, назва якого й відповідає змісту його предмету правового регулювання.

Тобто, аналіз, фактичного стану справ та тенденцій правового врегулювання правовідносин в Україні дає підстави для висновку, що якщо предмет правового регулювання галузей матеріального права визначає й назву кожної з цих галузей права, то в назвах галузей процесуального права ця закономірність ігнорується, внаслідок чого традиційна назва так званих процесуальних кодексів $\epsilon$ хибною і вони мали б називатися відповідно кодексами цивільного, кримінального, господарського судочинства, що відповідало б предмету правового регулювання кожного з них.

Ігнорування залежності назви галузі права від її предмета зумовлює організаційні проблеми й у практиці судочинства. Так, якщо врахувати, що згідно з Законом «Про судоустрій i статус суддів» судочинство в Україні здійснюється конституційним судом та судами загальної юрисдикції (ст. 3), а система судів загальної юрисдикції будується за принципами територіальності, спеціалізації та інстанційності (ст. 17). При цьому суди загальної юрисдикції спеціалізуються на розгляді цивільних, кримінальних, господарських, адміністративних справ, та справ про 
адміністративні правопорушення (ст. 18), що дає підстави розглядати їх спеціалізованими судами, які у своїй діяльності керуються відповідними процесуальними кодексами, то виникають питання, чи не зумовить поява інших спеціалізованих судів, наприклад, патентних, податкових, земельних, у справах неповнолітніх тощо, необхідності появи й інших відповідних процесуальних кодексів, i чи є у цьому потреба?

Крім того, якщо принцип єдності судової влади зумовлює необхідність уніфікації судової системи на основі створення єдиного і рівного для всіх суб'єктів правовідносин державного суду 3 покладанням на нього здійснення функцій правосуддя у справах, які виникають 3 будь-яких правовідносин у визначеному законом єдиному процесуальному порядку, то з огляду на це стає очевидною й об'єктивна необхідність уніфікації законодавства, що регламентує процедуру здійснення судочинства та створення єдиного кодексу судочинства, або, принаймні, кодексів публічного та приватного судочинства? [3, 22].

От тому, наприклад, сучасною наукою цивільного права й визнається, що предметом цивільного права є цивільно-правові відносини, тобто майнові відносини i пов'язані $з$ ними особисті немайнові відносини, а також інші особисті немайнові відносини $[4,9-10]$, що випливає зі ст. 1 ЦК України згідно 3 якою «Цивільним законодавством регулюються особисті немайнові та майнові відносини (цивільні відносини), засновані на юридичній рівності, вільному волевиявленні, майновій самостійності їх учасників». А це означає, що Цивільним кодексом
України визначені не лише права та обов'язки учасників зазначених правовідносин, а й процедуру їх peалізації.

Що ж до цивільно-процесуального законодавства, то у ст. 1 Цивільний процесуальний кодекс України визначає юрисдикцію та повноваження загальних судів щодо цивільних спорів та інших визначених цим Кодексом справ, встановлює порядок здійснення цивільного судочинства, що і $є$ предметом цієї галузі права, який і мав би впливати на й назву відповідного кодексу, який 3 урахуванням цього мав би бути Кодексом цивільного судочинства.

Адже не випадково в науці цивільно-процесуального права традиційними є визначення, що предметом цивільного процесуального права є: цивільне судочинство, процес, тобто урегульована цивільним процесуальним правом діяльність суду, осіб, які беруть участь у справі (свідків, експертів, перекладачів) та інших учасників процесу, а також органів судового виконання (судових виконавців) [5, 4]; суспільні відносини у сфері здійснення правосуддя в цивільних справах $[6,10]$ тощо.

Слід зазначити, що ці визначення предмета цивільнопроцесуального регулювання в цілому зміст цивільно-процесуальних відносин визначають правильно, однак, при науковому їх уточненні потрібно було б звернути увагу на те, що цивільно-процесуальні правовідносини урегульовані не «правом», а відповідним законодавством. Не варто при цьому судочинство у цивільних справах ототожнювати 3 «правосуддям», оскільки поняття «правосуддя» за змістом $€$ значно ширшим. Не випадково ст. 2 ЦПК 
визначені завдання не правосуддя, а «цивільного судочинства», успішне розв'язання яких й спрямоване на здійснення правосуддя.

Висновки. 3 урахуванням викладеного стає очевидним, що:

1) методологічне значення предмета правового регулювання полягає не тільки в тому, що він $\epsilon$ основним критерієм поділу правових норм на галузі права, а й тією ознакою, яка визначає і їхні назви;

2) правильний з методологічного погляду поділ правових норм на норми матеріального та норми процесуального права в українській правовій науці помилково використовується й як критерій поділу галузей права на галузі матеріального і процесуального права, що зумовило появу таких його галузей, як цивільно-процесуальне, кримінальнопроцесуальне та господарськопроцесуальне право, які супроводжуються й відповідними кодексами, назви яких предметам регулювання цих галузей не відповідають;

3) оскільки предметом цивільного процесуального права $є$ цивільне судочинство, тобто урегульована цивільним процесуальним законодавством діяльність суду, учасників справи, інших учасників судового провадження (свідків, експертів, пе- рекладачів), а також органів виконання судових рішень, спрямована на розв'язання суперечностей, що виникають з цивільних правовідносин, то вказана обставина мала б бути відображеною і в назві даної галузі права;

4) зміст предмета вказаної галузі права дає підстави для висновку, що й кодекс, який $є$ їі основним джерелом мав би іменуватися не Цивільним процесуальним кодексом, а Кодексом цивільного судочинства;

5) якщо системність правовідносин зумовлює і системність права, і системність законодавства, а принцип єдності судової влади який, у свою чергу, зумовлює необхідність уніфікації судової системи на основі створення єдиного та рівного для всіх суб'єктів правовідносин державного суду 3 покладанням на нього здійснення функцій правосуддя $\mathrm{y}$ справах, що виникають з будь-яких правовідносин у визначеному законом єдиному процесуальному порядку, то з огляду на це стає очевидною актуальність дослідження проблеми об'єктивної необхідність уніфікації законодавства, що регламентує процедуру здійснення судочинства та створення єдиного кодексу судочинства, або, принаймні, кодексу публічного та кодексу приватного судочинства.

\section{Список використаних джерел}

1. Дзера О. В. Вступ до цивільного права. Цивільне право України. Підручник. У 2х кн. Кн. 1. Київ : Юрінком Інтер, 2002. С. 19-23.

2. Керимов Д. А. Философские проблемы права. Москва : Наука, 1972. С. 297.

3. Котюк I. I. Основи теорії судового пізнання. Загальнотеоретичні аспекти : навчальний посібник. Ч. 1. Київ : ВПЦ «Київський університет», 2012. С. 22.

4. Цивільне право України : Підручник: У 2-х кн. / За ред. О. В. Дзери, Н. С. Кузнєцової. Київ : Юрінком Інтер, 2002. С. 9-10.

5. Советский гражданский процесс. Под ред. М. А. Гурвича. Москва : Высшая школа, 1975. С. 4.

6. Штефан М. Й. Цивільний процес. Підручник. Київ : Ін Юре, 1997. С. 10. 


\section{References}

Dzera, O. V. (2002). Vstup do tsyvilnoho prava. Tsyvilne pravo Ukrainy. Kn. 1. Kyiv: Yurinkom Inter [in Ukrainian].

Kerimov, D. A. (1972). Filosofskiye problemy prava. Moskva: Nauka [in Russian].

Kotiuk, I. I. (2012). Osnovy teorii sudovoho piznannia. Zahalnoteoretychni aspekty. Ch. 1. Kyiv: VPTs "Kyivskyi universytet" [in Ukrainian].

Dzera, O. V., Kuznietsova, N. S. (Red.). (2002). Tsyvilne pravo Ukrainy. Kyiv: Yurinkom Inter [in Ukrainian].

Gurvich, M. A. (Red.). (1975). Sovetskiy grazhdanskiy protsess. Moskva: Vysshaya shkola [in Russian].

Shtefan, M. I. (1997). Tsyvilnyi protses. Pidruchnyk. Kyiv: In Yure [in Ukrainian].

o. Kotiuk, Candidate of Legal Sciences, teaching assistant of the Department of Civil Procedure of the Institute of Law of Taras Shevchenko National University of Kyiv e-mail: aaasssdddfff@ukr.net; ORCID: 0000-0002-6464-2315

Yu. Sereda, Candidate of Legal Sciences, Associate Professor, Associate Professor of the Department of Constitutional, Administrative and Criminal law of the Educational and Scientific Institute "Law Institute of the State Higher Educational Institution "Kyiv National Economic University named after Vadym Hetman"

e-mail: advokatkpk@gmail.com; ORCID: 0000-0001-5244-3573

\section{Discussion aspects during traditional approaches to defining the subject of legal regulation}

The article clarifies the concepts of legal regulation, its object, subject and types based on the provisions of general theory of law. The attention is drawn to the fact that if public relations are the object of legal regulation, then legal relations are its subject. The legal relations mean those aspects of these relations that are regulated by legal norms and which therefore should arise, change and terminate according to these norms.

It is substantiated that the subject of legal regulation is the main basis not only for division of legal norms into branches of law, but also for definition of their names. The article emphasizes the interdependence of consistency of public relations and consistency of law and legislation. The attention is drawn to the fact that division of legal norms into norms of substantive law and norms of procedural law in Ukrainian legal science, which is correct in terms of methodology, and therefore is generally recognized, is mistakenly used as a criterion for dividing branches of law into branches of substantive and procedural law, which led to emergence of such branches as civil procedure law, criminal procedure law and economic procedure law, which are accompanied by relevant codes. At the same time, the logic of this approach by analogy determines the need for appropriate branches of procedural law that would accompany every other branch of substantive law - constitutional, administrative, family, labor, etc. However, there are no such branches of procedural law. There is a reason for that.

It is proved that considering the subject of legal regulation of these branches of law gives grounds to conclude that in fact legal relations developing in the pro- 
cess of relevant types of legal proceedings, resulting from civil, economic and criminal legal relations are the subject itself. As a result, these codes should be referred to as codes of judicial procedure, which fully relates to civil procedure law and name of the relevant code.

It is substantiated that if consistency of legal relations determines both consistency of law and consistency of legislation, and the principle of unity of judicial power that, in turn, necessitates the judicial system unification by creating a single state court equal for all subjects of legal relations with functions of justice in cases arising from any legal relations according to the procedural order determined by law, then taking this into account, the relevance of studying the problem of objective necessity of legislation unification, which governs the procedure for legal proceedings and creating a single code of judicial procedure, or at least the codes of public and private judicial procedure, becomes obvious.

Keywords: legal regulation; subject of legal regulation; criteria for dividing legal norms into branches of law; means of legal regulation; subject of civil procedure regulation; sources of civil procedure law. 